\title{
Effect of conventional and minimum tillage on physical and biochemical stabilization of soil organic matter
}

\author{
Anna Jacobs • Mirjam Helfrich • Susan Hanisch • \\ Ulrich Quendt • Rolf Rauber • Bernard Ludwig
}

Received: 29 October 2009 /Revised: 27 May 2010 /Accepted: 5 June 2010 / Published online: 20 June 2010

(C) Springer-Verlag 2010

\begin{abstract}
The objectives were to investigate (1) to which extent water-stable macro- and microaggregates sequester organic matter $(\mathrm{OM})$ in a minimum tillage (MT) system compared to a conventional tillage (CT) system and (2) if the content of biochemically stabilized OM differs between both tillage systems, and (3) to study the temporal dynamics of the distribution of aggregate size classes and of storage of OM within aggregates in the field. Surface soils $(0-5 \mathrm{~cm})$ and subsoils $(10-20 \mathrm{~cm})$ were sampled after fallow (March 2007) and directly after tillage (November 2007) from a long-term experimental field near Göttingen, Germany. Macroaggregates $(>0.25 \mathrm{~mm})$ were in general less abundant after fallow than directly after tillage. In March, only $21 \%$ (CT) and $45 \%$ (MT) of $\mathrm{C}_{\text {org }}$ was stored within macroaggregates in the surface soil, whereas in November, the percentages increased to $58 \%$ and $73 \%$, respectively. CT and MT soils of both depths were incubated as bulk soil $\left(\mathrm{CT}_{\text {bulk }}, \mathrm{MT}_{\text {bulk }}\right)$ and with macroaggregates disrupted $(<0.25 \mathrm{~mm})\left(\mathrm{CT}_{\mathrm{md}}, \mathrm{MT}_{\mathrm{md}}\right)$ for 28 days at $22^{\circ} \mathrm{C}$ and water content of $50 \%$ of the maximum water holding capacity. For the $\mathrm{MT}_{\text {bulk }}$ and $\mathrm{MT}_{\mathrm{md}}$ surface soils, $\mathrm{C}$ mineralization was significantly higher compared to the $\mathrm{CT}$ soils. Incubation of md soils did not generally result in a
\end{abstract}

A. Jacobs $\cdot$ M. Helfrich $\cdot$ S. Hanisch $\cdot$ U. Quendt • B. Ludwig ( $\varangle)$ Department of Environmental Chemistry, University of Kassel, 37213 Witzenhausen, Germany

e-mail: bludwig@uni-kassel.de

M. Helfrich

Institute of Agricultural Climate Research,

Johann Heinrich von Thünen-Institute,

38116 Braunschweig, Germany

R. Rauber

Department of Crop Sciences, University of Göttingen,

37075 Göttingen, Germany significantly higher $\mathrm{C}$ mineralization compared to the respective bulk soils, except for the $\mathrm{MT}_{\mathrm{md}}$ subsoil. Acid hydrolysis showed that the proportion of biochemically stabilized, nonhydrolysable, $\mathrm{C}_{\text {org }}$ to total $\mathrm{C}_{\text {org }}$ was lower in the MT than in the CT soils. Overall, the data indicate that the effect of physical stabilization of $\mathrm{OM}$ stored in the macroaggregates may not be a mechanism protecting very labile $\mathrm{C}$ with a turnover time of weeks, but that longer preservation likely occurs after macroaggregate transformation into microaggregates, and the surplus of OM found in the surface soil of MT does not only depend on the biochemically stabilized OM. Finally, our data suggest that the temporal variability of distribution of aggregate size classes in the field is large, but spatial and operator variability also contributed to the observed differences.

Keywords Acid hydrolysis · Incubation .

Macroaggregates · Potential mineralization .

Water-stable aggregates

\section{Introduction}

Sustaining the fertility of arable soils and reducing $\mathrm{CO}_{2}$ emissions from soil require an understanding of mechanisms leading to a sustainable sequestration of organic matter (OM). It was shown for various soil types and climatic regions that tillage systems that minimize soil disturbance (conservation tillage, minimum tillage [MT], reduced tillage, and no tillage [NT]) generally increase the storage of soil OM compared to conventionally tilled (CT) soils (Paustian et al. 2000; Six et al. 2000a, b; Kushwaha et al. 2001; Jacobs et al. 2009). However, the processes underlying this increased $\mathrm{OM}$ sequestration are not completely understood. 
In general, the stabilization of $\mathrm{OM}$ in soils, i.e., the protection of $\mathrm{OM}$ against microbial decomposition, may be mainly attributed to three mechanisms, namely, (1) spatial inaccessibility, (2) biochemical recalcitrance, and (3) organomineral association (von Lützow et al. 2006). However, the importance of each of these three mechanisms for $\mathrm{OM}$ stabilization can differ for each soil horizon and depends on several factors such as soil type and texture, mineralogical composition, and land use.

In arable soils, the formation of macroaggregates, whereby fresh organic residues are enclosed within aggregates, is regarded as an important process leading to the spatial inaccessibility of OM (Oades 1984; Balesdent et al. 2000). Recently, Helfrich et al. (2008) emphasized the importance of microaggregates to spatial inaccessibility of OM. In their study, macroaggregate formation implied rapid incorporation and thereby short-term protection of maize-derived $\mathrm{C}$ and $\mathrm{N}$. Moreover, macroaggregates allowed a transfer of maizederived $\mathrm{OM}$ into microaggregates within macroaggregates, which prevented the release of significant amounts of free particulate OM upon macroaggregate breakdown.

Tillage systems with minimized soil disturbance (MT, here defined as tillage reaching a maximum depth of $10 \mathrm{~cm}$ ) were reported to increase the occurrence and the stability of macroaggregates compared to CT soils (Paustian et al. 2000; Six et al. 2000a, b; Kushwaha et al. 2001; Jacobs et al. 2009), which was ascribed to various physical and biological factors, such as a reduced physical impact of machinery leading to less disruption of aggregates and a higher formation of macroaggregates due to a higher concentration of OM in the surface soil (Balesdent et al. 2000; Kushwaha et al. 2001; Bronick and Lal 2005; Jacobs et al. 2009). However, little is known about the temporal dynamics of the aggregate distribution in soils (Plante et al. 2002; De Gryze et al. 2006; Álvaro-Fuentes et al. 2007; Olchin et al. 2008).

In order to investigate the role of macroaggregates for protection of OM against microbial decomposition, several incubation experiments have been carried out using soils from $\mathrm{CT}$ and NT experiments with contrasting results about the increase in the $\mathrm{OM}$ mineralization after the disruption of macroaggregates (Beare et al. 1994; Oorts et al. 2006). An increasing size of a recalcitrant OM pool (isolated by acid hydrolysis) under NT compared to CT plots was reported by Collins et al. (2000), and it was attributed mainly to increasing soil organic carbon stocks. However, the contribution of recalcitrant to total $\mathrm{C}_{\text {org }}\left(\%\right.$ of $\left.\mathrm{C}_{\text {org }}\right)$ remained similar or even slightly decreased in the NT compared to CT plots (Collins et al. 2000).

Jacobs et al. (2009) suggested that long-term MT resulted in an enhanced physical protection of $\mathrm{OM}$ accounting for the higher concentrations of $\mathrm{C}_{\text {org }}$ and $\mathrm{N}$ in MT soils. However, density fractionation of the surface soil did not reveal more particulate OM occluded within aggregates but rather higher $\mathrm{C}_{\mathrm{org}}$ and $\mathrm{N}$ concentrations in the mineral fractions of MT than of CT soils (Jacobs et al. 2009). These findings were supported by the results of Jastrow (1996) and Zotarelli et al. (2007) who suggested that most of $\mathrm{OM}$ is sequestered as a mineral-associated fraction that is further occluded into aggregates.

Overall, several mechanisms that possibly contribute to an increased $\mathrm{OM}$ sequestration were suggested by various studies and are still discussed controversially. Furthermore, information on MT systems is scarce, since mainly NT systems have been investigated. We hypothesize that physical protection, and not biochemical stabilization, is the main reason for an enhanced preservation of OM in MT systems compared to CT systems, and that surplus OM is mainly located in water-stable microaggregates.

The objectives of our study were to investigate (1) to which extent water-stable macro- and microaggregates sequester OM in an MT system compared to a CT system and (2) if the content of biochemically stabilized OM differs between the two tillage systems, and (3) to study the temporal dynamics of the distribution of aggregate size classes among tillage systems in the field.

\section{Materials and methods}

Sampling site and sample processing

Our study was conducted on a long-term experimental site near Göttingen, Germany (Garte-Süd). The mean annual precipitation and temperature are $645 \mathrm{~mm}$ and $8.7^{\circ} \mathrm{C}$, respectively. The soil type is a Haplic Luvisol (WRB) derived from loess (15.1\% clay, $72.7 \%$ silt, $12.2 \%$ sand in $0-30 \mathrm{~cm}$, Ehlers et al. 2000). In 1970, two different tillage treatments were established with four field-replicates for each treatment: conventional tillage (CT) by mouldboard ploughing to $25-\mathrm{cm}$ depth and MT using a rotary harrow to 5- to 8-cm depth. Before 1970, the field had been mouldboard ploughed. The crops grown from 2003 to 2005 were winter wheat (Triticum aestivum L.) in 2003, pea (Pisum sativum L.) in 2004, and winter wheat (T. aestivum L.)/mustard (Sinapis alba L.) in 2005. All crop residues were incorporated by the respective tillage operations. In 2006, forage maize (Zea mays L.) was grown until September, where aboveground parts were harvested. The maize stubble was not incorporated, and the fields were bare fallows until the end of March 2007. The tillage operations were then carried out, and field bean (Vicia faba L.) was sown on the 29th of March 2007. Harvest took place on the 29th of August. Tillage operations were carried out on the 1st (CT) and 2nd (MT) of November 2007. Further site characteristics are given by Ehlers et al. (2000) and Jacobs et al. (2009).

Samples were taken in March 2007 after fallow (and before the tillage at the end of March) and on the 7th of 
November 2007, 5 (MT) and 6 (CT) days after tillage. In these 6 days, daily mean soil temperature was constant at $12^{\circ} \mathrm{C}$ (detected at 5-, 10-, and 20-cm depth). From each field replicate, a composite sample out of three subplots was taken from 0 - to $5-\mathrm{cm}$ (surface soil) and 10- to $20-\mathrm{cm}$ (subsoil) depth. Directly after sampling, samples were stored at $4^{\circ} \mathrm{C}$. Samples were carefully broken apart and sieved $(<10 \mathrm{~mm})$ at room temperature as soon as possible. Directly after sieving, samples were dried at $40^{\circ} \mathrm{C}$ for $48 \mathrm{~h}$. In the following days, fractionation was carried out as described below.

Contents of $\mathrm{C}_{\text {org }}$ and $\mathrm{N}$ for the surface soils $(0-5 \mathrm{~cm})$ and subsoils $(10-20 \mathrm{~cm})$ are shown in Table 1 . The sampling depths 0 to 5 and 10 to $20 \mathrm{~cm}$ were chosen in order to distinguish accurately between those layers that were affected by MT and those that were not. However, one has to keep in mind that the $10-$ to $20-\mathrm{cm}$ depth was not entirely representative of the plough layer of the CT treatment. At the sampling date of November, an accumulation of the harvest residues was visible in the lower third of the Ap horizon of the CT treatment.

Separation of water-stable aggregates and $\mathrm{OM}$ within aggregate size classes

The temporal dynamics of water-stable aggregates was studied by sampling soils in March 2007 (after fallow, Jacobs et al. 2009) and directly after tillage in November 2007. We used the method developed by Cambardella and Elliott (1993) and modified by Six et al. (1998). Briefly, 100 g (LP6200S; Sartorius, Göttingen, Germany) of dry soil $(<10 \mathrm{~mm})$ was placed on a $2-\mathrm{mm}$ sieve and submerged into distilled water for $10 \mathrm{~min}$ to allow slaking. Thereafter, the sieve was moved up and down into the water with 50 repetitions. Water-stable aggregates remaining on the mesh (large macroaggregates: $2-10 \mathrm{~mm}$ ) were collected, vacuum filtered $(<0.45 \mu \mathrm{m})$ to remove water, dried at $40^{\circ} \mathrm{C}$ for $48 \mathrm{~h}$ on the filter, and weighed (LP3200D, Sartorius). Aggregates that passed the 2-mm mesh were poured onto the next smaller mesh size, and the fractionation procedure was

Table 1 Site properties (bulk soil $<2 \mathrm{~mm}$ ) at November 2007 for different tillage systems and sampling depths (means and standard errors, $n=4$ )

\begin{tabular}{llll}
\hline Depth $(\mathrm{cm})$ & Tillage system & $\mathrm{C}_{\text {org }}\left(\mathrm{g} \mathrm{kg}^{-1}\right)$ & $\mathrm{N}\left(\mathrm{g} \mathrm{kg}^{-1}\right)$ \\
\hline $0-5$ & Conventional & $9.3(0.3)^{\mathrm{A}}$ & $1.02(0.03)^{\mathrm{A}}$ \\
$10-20$ & & $9.4(0.4)^{\mathrm{A}}$ & $1.04(0.03)^{\mathrm{A}}$ \\
$0-5$ & Minimum & $15.8(0.4)^{\mathrm{B}}$ & $1.58(0.02)^{\mathrm{B}}$ \\
$10-20$ & & $9.2(0.7)^{\mathrm{A}}$ & $0.95(0.03)^{\mathrm{A}}$ \\
\hline
\end{tabular}

Letters indicate significant differences $(p \leq 0.05)$ between tillage systems. continued as described above. Mesh sizes used were $1 \mathrm{~mm}$ for medium macroaggregates, $0.25 \mathrm{~mm}$ for small macroaggregates, and $0.053 \mathrm{~mm}$ for microaggregates. Finally, the supernatant (silt and clay together with finest microaggregates $<0.053 \mathrm{~mm})$ was precipitated with $0.5 \mathrm{M} \mathrm{AlCl}_{3}(5 \mathrm{~mL}$ on $2 \mathrm{~L}$ of supernatant). To recover the $<0.053-\mathrm{mm}$ fraction after precipitation, the water was siphoned off, then the deposit was dried at $40^{\circ} \mathrm{C}$ for $48 \mathrm{~h}$ and weighed (LP3200D, Sartorius). All fractions were ball milled (Retsch, Haan, Germany), and $\mathrm{C}_{\text {org }}$ and $\mathrm{N}$ concentrations were determined in all water-stable aggregate size classes obtained and in the bulk soil. Carbonates were destroyed by $10 \% \mathrm{HCl}$ prior to analysis (Elementar Vario El; Heraeus, Hanau, Germany).

For this site, Jacobs et al. (2009) showed that the calculation of the $\mathrm{C}_{\text {org }}$ and $\mathrm{N}$ concentrations within aggregate size classes on a sand-free basis (Elliott et al. 1991; Six et al. 2000b) did not have a significant effect on the distribution of $\mathrm{OM}$ among the size classes investigated. Thus, in this study, $\mathrm{C}_{\text {org }}$ and $\mathrm{N}$ concentrations of the respective aggregate size classes are expressed on a whole soil basis.

Operator variability was small to moderate for the five aggregate fractions. For the surface soil sampled in November, yields (dry matter \%, means and standard errors, $n=4)$ in the fractions 2 to 10,1 to $2,0.25$ to 1 , 0.053 to 0.25 , and $<0.053 \mathrm{~mm}$ of the MT treatments were 6.2 (0.9), 6.1 (1.0), 53.5 (1.1), 20.6 (1.9), and 16.4 (3.0) (Fig. 1), obtained by U. Quendt. A. Sawallisch obtained the following yields (dry matter \%, means and standard errors, $n=4)$ of the named fractions: $7.0(0.7), 5.0(0.9), 52.3(1.2)$, 18.2 (0.7), and 16.9 (2.0), indicating a small operator variability. For the surface soil of the CT treatment, yields were affected to a moderate extent, but generally within the range of the standard errors. Yields (dry matter \%, means and standard errors, $n=4)$ of the named fractions were $0.4(0.1)$, $0.6(0.1), 55.3(2.0), 24.5(2.0)$, and $18.3(0.3)$ obtained by A. Sawallisch compared to $0.6(0.2), 0.8(0.1), 53.7$ (5.0), 28.2 (4.5), and 17.1 (1.3) obtained by U. Quendt (Fig. 1).

Incubation experiment

The incubation was carried out with the surface soils and subsoils taken in November 2007 (sieved $<10 \mathrm{~mm}$ and dried at $40^{\circ} \mathrm{C}$ for $48 \mathrm{~h}$ ) in the following treatments: (1) CT, bulk soil $<10 \mathrm{~mm}$ $\left(\mathrm{CT}_{\text {bulk }}\right)$, (2) $\mathrm{CT}$, macroaggregates destroyed $\left(\mathrm{CT}_{\mathrm{md}}\right)$, (3) MT, bulk soil $<10 \mathrm{~mm}\left(\mathrm{MT}_{\text {bulk }}\right)$, (4) MT, macroaggregates destroyed $\left(\mathrm{MT}_{\mathrm{md}}\right)$. For the $\mathrm{CT}_{\mathrm{md}}$ and $\mathrm{MT}_{\mathrm{md}}$ treatments, all naturally occurring macroaggregates were gently destroyed by a mortar, and the soil was passed through a $0.25-\mathrm{mm}$ mesh prior to incubation in order to guarantee complete macroaggregate disruption.

For each treatment, $40 \mathrm{~g}$ of soil (either md or bulk soil) were incubated in glass jars at $50 \%$ of the maximum water holding capacity and $22^{\circ} \mathrm{C}$ for 28 days in the dark. Soil 
Fig. 1 Total yield of water-stable aggregate size classes (means and standard errors, $n=4$ ) among tillage systems (CT and MT) and sampling depths in March 2007 (Jacobs et al. 2009; subfigure a, b) and November 2007 (subfigure $\mathbf{c}, \mathbf{d}$ ). Lowercase letters indicate significant differences ( $p \leq$ 0.05 ) among tillage systems. Uppercase letters indicate significant differences $(p \leq 0.05)$ between sampling dates
$0-5 \mathrm{~cm}$

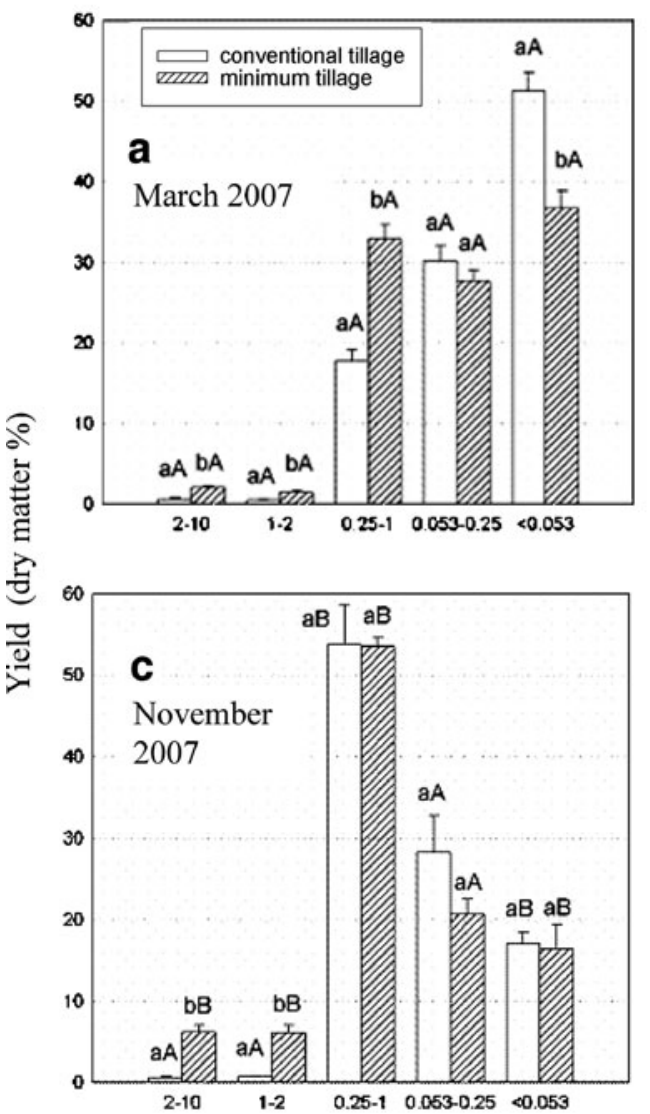

$10-20 \mathrm{~cm}$
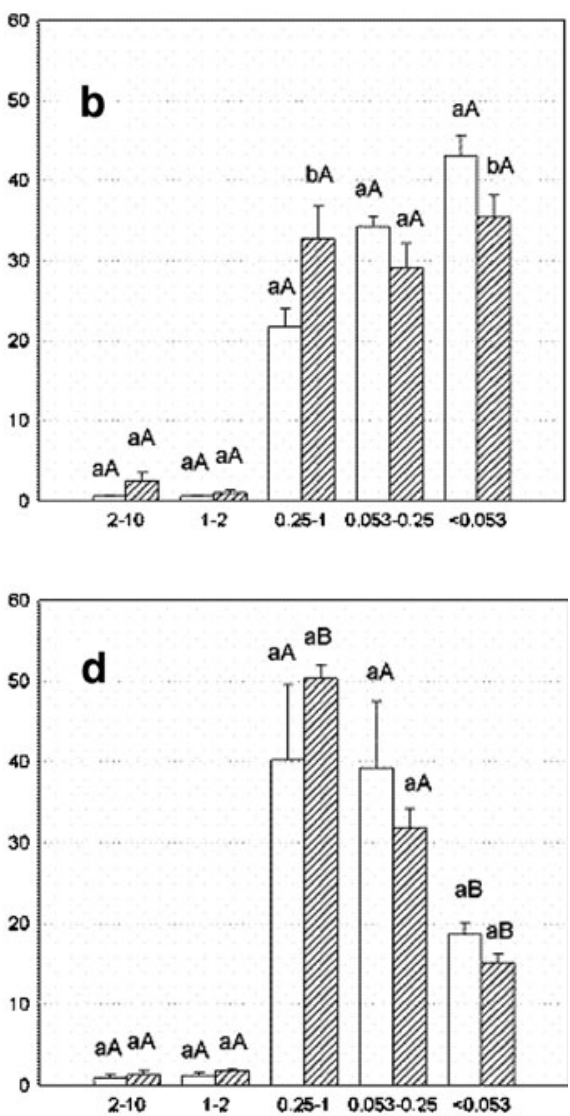

Size classes of water-stable aggregates $(\mathrm{mm})$

moisture was controlled regularly by weighing and corrected if necessary by adding distilled water.

Carbon and $\mathrm{N}$ concentrations were determined on all soil samples before (day 0) and at the end of incubation (day 28) by dry combustion (Vario Max, Elementar, Hanau, Germany). Carbonates were determined by the Scheibler method.

Soil microbial $\mathrm{C}\left(\mathrm{C}_{\text {mic }}\right)$ and $\mathrm{N}\left(\mathrm{N}_{\text {mic }}\right)$ were determined after 28 days of incubation by the chloroform-fumigationextraction method (Vance et al. 1987). Two portions equivalent to $10-\mathrm{g}$ dry soil were taken from each soil sample. One portion was fumigated for $24 \mathrm{~h}$ with ethanolfree $\mathrm{CHCl}_{3}$ and was extracted with $40-\mathrm{mL} 0.5 \mathrm{M} \mathrm{K}_{2} \mathrm{SO}_{4}$. A nonfumigated portion was extracted at the same time fumigation commenced. After determination of the $\mathrm{C}$ and $\mathrm{N}$ concentrations in the extract (Dima-TOC 100, Dima-N; Dimatec, Essen, Germany), the $\mathrm{C}_{\text {mic }}$ and $\mathrm{N}_{\text {mic }}$ concentrations were calculated as follows: $\mathrm{C}_{\text {mic }}=E_{\mathrm{C}} / k_{\mathrm{EC}}$, where $E_{\mathrm{C}}$ was $\left(\mathrm{C}_{\text {org }}\right.$ extracted from fumigated samples $)-\left(\mathrm{C}_{\mathrm{org}}\right.$ extracted from nonfumigated samples) and $k_{\mathrm{EC}}$ was 0.45 (Joergensen et al. 1995). The same equation was applied for $\mathrm{N}_{\text {mic }}$ but using $k_{\mathrm{EN}}=0.54$ (Joergensen et al. 1995).

Basal respiration (Heinze et al. 2009) of soil was determined by trapping $\mathrm{CO}_{2}$ with $5-\mathrm{mL} 0.5 \mathrm{M} \mathrm{NaOH}$, which was replaced after $1,3,7,10,14,21$, and 28 days.
The trapped $\mathrm{CO}_{2}$ was precipitated as $\mathrm{BaCO}_{3}$ by $5 \mathrm{~mL}$ of saturated $\mathrm{BaCl}_{2}$ solution, and the residual $\mathrm{NaOH}$ was titrated to $\mathrm{pH} 8.3$ by $0.5 \mathrm{M} \mathrm{HCl}$. The amount of $\mathrm{CO}_{2}$ evolved $\left(\mu \mathrm{g}(\mathrm{g} \text { soil })^{-1}\right.$ day $\left.^{-1}\right)$ was calculated as follows:

$$
\begin{aligned}
\mathrm{CO}_{2}-\mathrm{C} \text { emission }= & {[((B-S) \times M-E / \mathrm{DW})-1,000] / } \\
& \text { days of incubation }
\end{aligned}
$$

where $B$ is the amount $(\mathrm{mL})$ of acid needed to titrate the $\mathrm{NaOH}$ of the blank, $S$ is the amount of acid $(\mathrm{mL})$ needed to titrate $\mathrm{NaOH}$ in the samples, $M$ is the molarity of the $\mathrm{HCl}$, $E$ is the equivalent weight (6) of $\mathrm{C}$ to $\mathrm{OH}^{-}$ions in the titration reaction, and DW is the dry weight of the soil (g).

\section{Acid hydrolysis}

In order to determine the biochemically stabilized OM pool, the samples taken in November 2007 were subjected to acid hydrolysis as described by Plante et al. (2006), but slightly modified. Briefly, $0.5 \mathrm{~g}$ of sample was treated with $25-\mathrm{mL}$ $6 \mathrm{M} \mathrm{HCl}$ for $16 \mathrm{~h}$ under reflux at $100^{\circ} \mathrm{C}$. Thereafter, samples were washed three times with $40-\mathrm{mL}$ distilled $\mathrm{H}_{2} \mathrm{O}$, the supernatant was discarded after centrifugation at 5,200 $\mathrm{g}$ for $15 \mathrm{~min}$, and the soil was freeze-dried. The remaining, 
nonhydrolysable, $\mathrm{C}_{\text {org }}$ and $\mathrm{N}$ fractions, which are regarded as biochemically stabilized, recalcitrant soil organic matter (SOM) pools (Paul et al. 2006), were determined by dry combustion (Vario Max, Elementar, Hanau, Germany).

Equivalent soil mass approach

For the surface soils of the CT and MT systems, we calculated the $\mathrm{C}$ mass per unit area in an equivalent soil mass as described by Ellert et al. (2001), and data are given in $\mathrm{kg} \mathrm{C} \mathrm{m}^{-2}$ in $68-\mathrm{kg}$ soil (Table 2). For the calculations, the depths considered ranged from $0-5$ to $0-5.4 \mathrm{~cm}$, depending on the bulk densities (Table 2), and we assumed that the bulk densities measured in the 0 - to $5-\mathrm{cm}$ depths were also approximately valid down to $5.4 \mathrm{~cm}$

\section{Statistical analysis}

Means and standard errors were calculated for each parameter detected within each sampling depth and for each treatment. For the investigation of differences between water-stable aggregate size classes and of the proportion of biochemically stabilized $\mathrm{OM}$, both tillage systems were evaluated by a $t$-test. A paired $t$ test was performed for each tillage system and sampling depth to evaluate the temporal variation of water-stable aggregates and $\mathrm{C}_{\text {org }}$ stored within the aggregate size classes between the two sampling dates. We carried out an analysis of variance analysis followed by a Student-Newman-Keuls test including tillage system and aggregate treatment as fixed factors. Each of the sampling depths was investigated separately. The level of significance was fixed at $\alpha=0.05$. All statistical analyses were carried out using GLM of Statistica 7, Statsoft (Tulsa, USA).

\section{Results and discussion}

Total contents of $\mathrm{C}_{\text {org }}$ and $\mathrm{N}$ in soils

Thirty-seven years of two different tillage systems resulted in significant differences in $\mathrm{C}_{\text {org }}$ and $\mathrm{N}$ contents in the surface soil: $15.8 \mathrm{~g} \mathrm{~kg}^{-1} \mathrm{C}_{\mathrm{org}}$ were present after tillage in November 2007 in the 0 - to $5-\mathrm{cm}$ depth of the MT system compared to $9.3 \mathrm{~g} \mathrm{~kg}^{-1}$ of the CT system (Table 1). This difference is more pronounced than in March 2007, where the values were 16.3 (MT) and 13.3 (CT) $\mathrm{g} \mathrm{kg}^{-1}$ (Jacobs et al. 2009). The same pattern as for the $C_{\text {org }}$ contents was observed for the $\mathrm{N}$ contents in the surface soils. However, in the subsoils, no significant differences between tillage systems were observed for $\mathrm{C}_{\text {org }}$ and $\mathrm{N}$ for either sampling date. The higher $\mathrm{C}_{\text {org }}$ content in the surface soil in March than November 2007 probably depended on the fact that maize stubble was not incorporated after the maize harvest in September 2006.

In November 2007, 5 (MT) to 6 days (CT) after tillage, an intensive turnover of $\mathrm{C}_{\text {org }}$ in the soil was likely due to the incorporation of harvest residues and due to a possible breakup of aggregates by tillage. Thus, one sampling date with such intensive turnover may create artefacts in evaluating long-term effects of tillage systems on $\mathrm{C}_{\text {org }}$ storage. In our study, spatial variability of $C_{\text {org }}$ contents in November was small (Table 1), but no attempt was made in this study to sample the plots in exactly the same spots on both sampling dates by using a global positioning system. Thus, the variance given in Table 1 is likely not a true measure of the spatial variability.

A calculation of the $\mathrm{C}_{\text {org }}$ stocks in the surface soils using the equivalent soil mass approach suggests that between March and November 2007, 0.27 (CT) and 0.04 (MT) kg C $\mathrm{m}^{-2}$ in $68-\mathrm{kg}$ soil was lost in the surface soil (Table 2). The large $\mathrm{C}$ loss as suggested for the CT treatment in 8 months is unlikely for two reasons. First, steady-state systems show much smaller inputs and outputs than such a $\mathrm{C}$ loss. For instance, Ludwig et al. (2007) reported C inputs to the Ap horizon of 0.09 to $0.24 \mathrm{~kg} \mathrm{C} \mathrm{m}^{-2}$ for winter wheat and 0.06 to $0.12 \mathrm{~kg} \mathrm{C} \mathrm{m}^{-2}$ for spring barley in the Bad Lauchstädt trial, and since stocks were approximately constant (with a large spatial variability) in the fertilization treatments, outputs were probably of the same order (Ludwig et al. 2007). Second, tillage was carried out twice between the two sampling dates, resulting in a slight (MT: down to 5$8 \mathrm{~cm}$ ) or intensive mixing (CT: down to $25 \mathrm{~cm}$ ) of the soil, which makes an interpretation difficult for the surface soil of the CT system. Spatial heterogeneity and mixing during tillage were probably the main reason for the large deviation in $\mathrm{C}_{\text {org }}$ stocks between sampling dates.

Table 2 Bulk densities (means and standard errors, $n=4$ in March and $n=2$ in November) and stocks of $\mathrm{C}_{\text {org }}$ (means and standard errors, $n=4$ ) on an equivalent soil mass approach for the surface soils of different tillage systems (CT and MT) and two sampling dates

\begin{tabular}{lllll}
\hline $\begin{array}{l}\text { Tillage } \\
\text { system }\end{array}$ & $\begin{array}{l}\text { Sampling date in } \\
2007\end{array}$ & $\begin{array}{l}\text { Bulk density in } \\
0-5 \mathrm{~cm}\left(\mathrm{~g} \mathrm{~cm}^{-3}\right)\end{array}$ & $\begin{array}{l}\text { Depth considered in the equivalent soil mass } \\
\text { approach }(\mathrm{cm})\end{array}$ & $\begin{array}{l}\mathrm{C}_{\text {org }} \text { stock (kg C m } \mathrm{m}^{-2} \text { in } 68-\mathrm{kg} \\
\text { soil) }\end{array}$ \\
\hline $\mathrm{CT}$ & March & $1.36(0.09)$ & $0-5$ & $0.90(0.17)$ \\
& November & $1.36(0.19)$ & $0-5$ & $0.63(0.09)$ \\
MT & March & $1.25(0.04)$ & $0-5.4$ & $1.11(0.08)$ \\
& November & $1.33(0.09)$ & $0-5.1$ & $1.07(0.08)$ \\
\hline
\end{tabular}




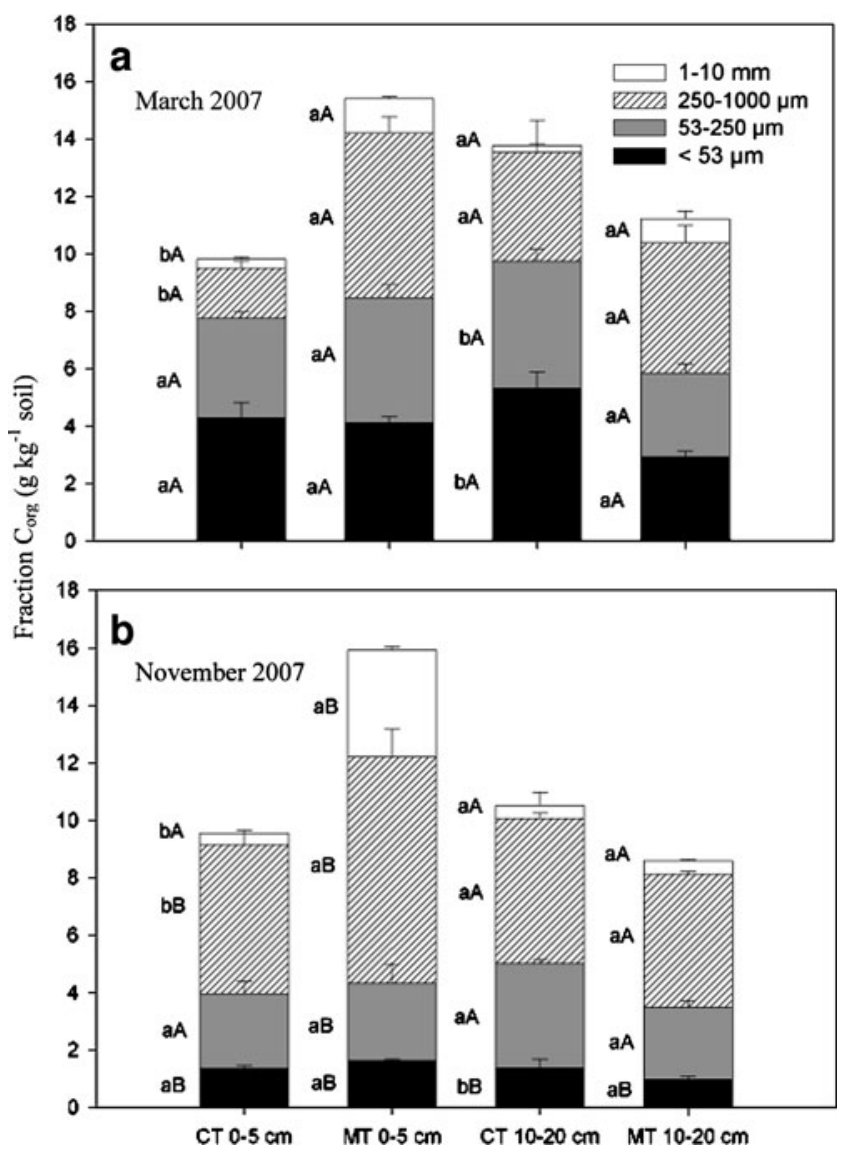

Fig. $2 \mathrm{C}_{\text {org }}$ concentration of water-stable aggregate size classes $(<10 \mathrm{~mm})$ per kilogram soil (means and standard errors, $n=4)$ among tillage systems (CT and MT) and sampling depths in March 2007 (modified after Jacobs et al. 2009; subfigure a) and November 2007 (subfigure b). Lowercase letters indicate significant differences $(p \leq$ $0.05)$ among tillage systems. Uppercase letters indicate significant differences $(p=0.05)$ between sampling dates

In order to assess the effect of different tillage systems on the entire soil profiles, greater depth ranges than used in our study have to be considered. For a site (Garte-Nord) close to our study site (Garte-Süd), Stockfisch et al. (1999) reported slightly higher $\mathrm{C}_{\text {org }}$ stocks in the 0 - to $50-\mathrm{cm}$ profile in MT than in $\mathrm{CT}$ after 20 years of different tillage systems.

Temporal variability of occurrence of different water-stable aggregate size classes and OM stored within size-classes

The separation of the soil samples taken in November 2007 into different size classes of water-stable aggregates showed a higher occurrence of macroaggregates $(>0.25 \mathrm{~mm})$ in the surface soil $(0-5 \mathrm{~cm})$ of MT than of CT (Fig. 1c). This was pronounced especially for the size classes 1 to 2 and 2 to $10 \mathrm{~mm}$. The subsoil followed the same trend but with no significant differences between the tillage treatments (Fig. 1d), thus, confirming those detected in March 2007 for the same site (Fig. 1a, b; Jacobs et al. 2009) and also for a tropical agroecosystem (Kushwaha et al. 2001). Jacobs et al. (2009) outlined that a higher occurrence of water-stable macroaggregates under MT can be attributed (1) to a reduced physical impact by the machinery leading to less disruption of aggregates than under CT or (2) to a higher formation of macroaggregates due to a higher concentration of $\mathrm{OM}$ in the surface soil.

In November 2007, directly after tillage (Fig. 1c, d), macroaggregates, especially the size class 0.25 to $1 \mathrm{~mm}$, were significantly more abundant under MT than in March 2007 after fallow (Jacobs et al. 2009; Fig. 1a, b). The increase of the contents of smaller macroaggregates $(0.25-1 \mathrm{~mm})$ with

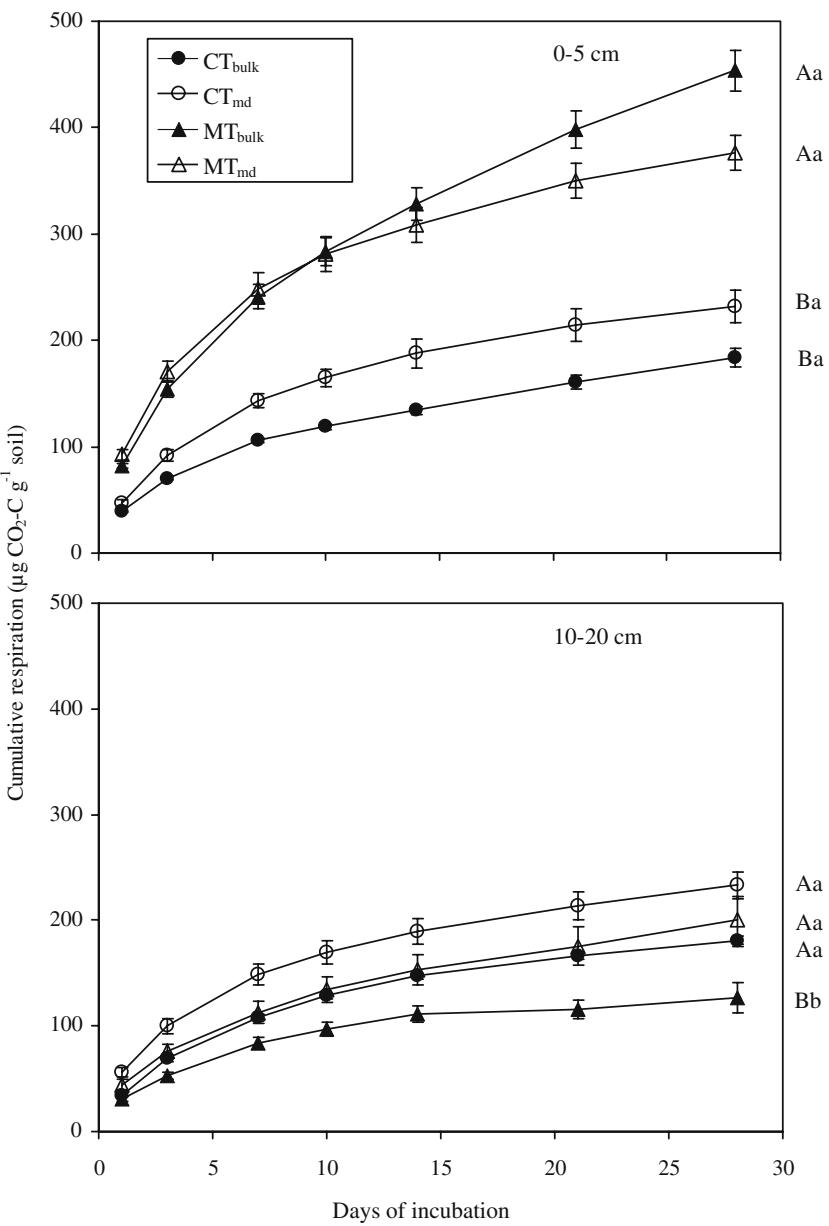

Fig. 3 Cumulative basal respiration during incubation among tillage systems (CT and MT), aggregate treatments, and sampling depths (means and standard errors, $n=4)$. Capital letters indicate significant differences $(p \leq 0.05)$ between tillage systems with the same aggregate treatment $\left(\mathrm{CT}_{\text {bulk }}\right.$ vs. $\mathrm{MT}_{\text {bulk }}, \mathrm{CT}_{\mathrm{md}}$ vs. $\left.\mathrm{MT}_{\mathrm{md}}\right)$; lowercase letters indicate significant differences $(p \leq 0.05)$ between aggregate treatments of the respective tillage treatment $\left(\mathrm{CT}_{\text {bulk }}\right.$ vs. $\mathrm{CT}_{\mathrm{md}}, \mathrm{MT}_{\text {bulk }}$ vs. $\left.\mathrm{MT}_{\mathrm{md}}\right)$. Probability values were aggregate treatment 0.41 , tillage system $<0.01$, aggregate treatment $\times$ tillage system $<0.01$ at 0 to $5 \mathrm{~cm}$; and aggregate treatment $<0.01$, tillage system 0.01 , aggregate treatment $x$ tillage system 0.39 at 10 to $20 \mathrm{~cm}$ 
respect to March was larger in CT than MT. This was pronounced in the surface soil, but the subsoil followed the same trend. However, spatial and operator variability have also contributed to the observed changes in the distribution of aggregate size classes. Additionally, one has to keep in mind that the method uses dried soil. Since drying of soil is known as an aggregate forming process, the results obtained by this method do not entirely reflect the field state aggregation.

The marked contents of smaller macroaggregates in the CT treatment after tillage suggest that physical disruption of aggregates by the plough may mainly affect the larger macroaggregates, resulting in small yields of large macroaggregates compared to MT as observed (Fig. 1). Moreover, the data suggest that during the cropping of field bean, differences in the aggregate distribution between the two tillage systems levelled off. The slightly larger contents of macroaggregates under MT suggest that more macroaggregates were formed directly after tillage due to the input of fresh plant residues. Daraghmeh et al. (2009) reported a significant temporal variation in wet aggregate stability (WAS) over the year for a Danish sandy loam under different tillage systems. They found that WAS was lowest in winter (December) and higher shortly after tillage (October) and in summer. The low WAS in winter was probably due to the interaction of freeze/thaw cycles with soil moisture, whereas the recovery of WAS from spring onwards probably depended on the increasing biological activity.
The calculation of the $\mathrm{C}_{\text {org }}$ concentration (expressed as $\mathrm{g} \mathrm{kg}^{-1}$ soil) in the size classes of water-stable aggregates indicated that the major part of $\mathrm{C}_{\text {org }}(58 \%$ and $73 \%$ for CT and MT surface soils, respectively, and $59 \%$ and $57 \%$ for $\mathrm{CT}$ and MT subsoils, respectively) was sequestered within macroaggregates $(>0.25 \mathrm{~mm})$ in November 2007 (Fig. 2b). The same occurred for total $\mathrm{N}$ (data not shown). Thus, macroaggregates, especially the size class 0.25 to $1 \mathrm{~mm}$, were the most important fraction sequestering of $\mathrm{OM}$ directly after tillage (Fig. 2b), but this OM sequestration is short-lived as discussed below. The comparison between the tillage systems revealed a significantly higher amount of $\mathrm{OM}$ within the macroaggregate fractions of MT than of CT surface soils (Fig. 2b). In a comparable tillage system, Kushwaha et al. (2001) also found that macroaggregates stored the surplus of OM in MT surface soils, and the same was reported by Beare et al. (1997) for an NT soil. In March 2007 after fallow, microaggregates and silt and clay particles were more abundant and more important in storing $\mathrm{C}_{\text {org }}(79 \%$ and $55 \%$ for CT and MT surface soils, respectively, and $72 \%$ and $53 \%$ for CT and MT subsoils, respectively) than macroaggregates (Figs. 1a,b and 2a). However, a comparison of CT with MT surface soils showed that the surplus of $\mathrm{C}_{\text {org }}$ stored under MT was located within the macroaggregate fractions.

Therefore, our interpretation is that a considerable number of new macroaggregates were formed (as shown

Table 3 Microbial biomass and different indices of OM decomposition after 28 days of incubation (means and standard errors, $n=4$ ) for the incubation experiment with $\mathrm{CT}$ and $\mathrm{MT}$ bulk soils $\left(\mathrm{CT}_{\text {bulk }}, \mathrm{MT}_{\text {bulk }}\right)$ and soils with destroyed macroaggregates $\left(\mathrm{CT}_{\mathrm{md}}, \mathrm{MT}_{\mathrm{md}}\right)$

\begin{tabular}{|c|c|c|c|c|c|}
\hline $\begin{array}{l}\text { Sampling } \\
\text { depth }(\mathrm{cm})\end{array}$ & Soil & $\mathrm{C}_{\text {mic }}\left(\mu \mathrm{g} \mathrm{g}^{-1}\right)$ & $\mathrm{N}_{\text {mic }}\left(\mu \mathrm{g} \mathrm{g}^{-1}\right)$ & $\begin{array}{l}\text { Percentage of organic } \mathrm{C} \\
\text { present as } \mathrm{C}_{\text {mic }}(\%)\end{array}$ & $\begin{array}{l}\text { Percentage of organic } \mathrm{C} \\
\text { evolved as } \mathrm{C}-\mathrm{CO}_{2}(\%)\end{array}$ \\
\hline \multirow[t]{8}{*}{$0-5$} & $\mathrm{CT}_{\text {bulk }}$ & $99(12)^{\mathrm{Aa}}$ & $17(3)^{\mathrm{Aa}}$ & $1.01(0.09)^{\mathrm{Aa}}$ & $2.03(0.17)^{\mathrm{Aa}}$ \\
\hline & $\mathrm{CT}_{\mathrm{md}}$ & $56(11)^{\mathrm{Aa}}$ & $11(2)^{\mathrm{Aa}}$ & $0.57(0.10)^{\mathrm{Ab}}$ & $2.49(0.21)^{\mathrm{Aa}}$ \\
\hline & $\mathrm{MT}_{\text {bulk }}$ & $358(27)^{\mathrm{Bc}}$ & $44(7)^{\mathrm{Bb}}$ & $2.32(0.15)^{\mathrm{Bc}}$ & $2.85(0.10)^{\mathrm{Ba}}$ \\
\hline & $\mathrm{MT}_{\mathrm{md}}$ & $222(17)^{\mathrm{Bb}}$ & $28(6)^{\mathrm{Aa}}$ & $1.49(0.09)^{\mathrm{Bd}}$ & $2.50(0.13)^{\mathrm{Aa}}$ \\
\hline & Probability values & & & & \\
\hline & Aggregate treatment & $<0.01$ & $<0.05$ & $<0.01$ & 0.72 \\
\hline & Tillage system & $<0.01$ & $<0.01$ & $<0.01$ & 0.02 \\
\hline & Aggregate treatment $\times$ tillage system & 0.02 & 0.32 & 0.09 & 0.03 \\
\hline \multirow[t]{8}{*}{$10-20$} & $\mathrm{CT}_{\text {bulk }}$ & $131(4)^{\mathrm{Aa}}$ & $16(2)^{\mathrm{Aa}}$ & $1.38(0.07)^{\mathrm{Aa}}$ & $1.92(0.07)^{\mathrm{Aa}}$ \\
\hline & $\mathrm{CT}_{\mathrm{md}}$ & $117(15)^{\mathrm{Aa}}$ & $11(2)^{\mathrm{Ab}}$ & $1.17(0.14)^{\mathrm{Aa}}$ & $2.32(0.07)^{\mathrm{Aa}}$ \\
\hline & $\mathrm{MT}_{\text {bulk }}$ & $118(6)^{\mathrm{Aa}}$ & $13(1)^{\mathrm{Ab}}$ & $1.38(0.10)^{\mathrm{Aa}}$ & $1.41(0.22)^{\mathrm{Ab}}$ \\
\hline & $\mathrm{MT}_{\mathrm{md}}$ & $84(6)^{\mathrm{Bb}}$ & $8(0)^{\mathrm{Ab}}$ & $0.95(0.05)^{\mathrm{Ab}}$ & $2.32(0.25)^{\mathrm{Aa}}$ \\
\hline & Probability values & & & & \\
\hline & Aggregate treatment & 0.02 & $<0.01$ & $<0.01$ & $<0.01$ \\
\hline & Tillage system & 0.03 & 0.08 & 0.26 & 0.16 \\
\hline & Aggregate treatment $\times$ tillage system & 0.27 & 0.94 & 0.27 & 0.16 \\
\hline
\end{tabular}

Capital letters indicate significant differences $(p \leq 0.05)$ between tillage systems with the same aggregate treatment $\left(\mathrm{CT}_{\text {bulk }} \mathrm{vs}_{\mathrm{S}} \mathrm{MT}_{\text {bulk }}, \mathrm{CT}_{\mathrm{md}} \mathrm{vs}\right.$. $\left.\mathrm{MT}_{\mathrm{md}}\right)$; lowercase letters indicate significant differences $(p \leq 0.05)$ between aggregate treatments of the respective tillage treatment $\left(\mathrm{CT}_{\text {bulk }} \mathrm{vs}\right.$. $\mathrm{CT}_{\text {md }}, \mathrm{MT}_{\text {bulk }}$ vs. $\mathrm{MT}_{\mathrm{md}}$ ). 
for our sampling in November) directly after tillage (and thus after residue incorporation). With ongoing time after tillage (as observed for the sampling in March 2007, which was 10 months after the last tillage and residue incorporation), macroaggregates disrupt into microaggregates, the latter being assumed to provide longer-term protection for OM (Paustian et al. 2000). This is in accordance with the previous finding that the turnover of macroaggregates is rapid if fresh residue inputs are lacking (e.g., Helfrich et al. 2008). However, two sampling dates are not adequate to provide the basis for accurate quantitative estimates of aggregate turnover. For instance, Plante et al. (2002) reported that soil macroaggregate mean residence times in different soils ranged from 4 to 95 days, where aggregate dynamics were generally two to three times more rapid in a Gray Luvisol compared to a Black Chernozem. De Gryze et al. (2006) estimated turnover times for macroaggregates and microaggregates to be 30 and 88 days, respectively.

Effects of tillage system and macroaggregate disruption on OM decomposition and microbial activity within the incubation experiment

After 28 days of incubation at $22^{\circ} \mathrm{C}$ and a water content of $50 \%$ of the maximum water holding capacity, cumulative $\mathrm{CO}_{2}-\mathrm{C}$ emission was significantly higher from the MT $\left(\mathrm{MT}_{\text {bulk }}, \mathrm{MT}_{\mathrm{md}}\right)$ than from the $\mathrm{CT}\left(\mathrm{CT}_{\text {bulk }}, \mathrm{CT}_{\mathrm{md}}\right)$ surface soils (Fig. 3). Furthermore, the specific respiration (percentage of organic $\mathrm{C}$ evolved as $\mathrm{C}-\mathrm{CO}_{2}$ ) showed the highest value in $\mathrm{MT}_{\text {bulk }}$ surface soils (Table 3). Higher potential OM mineralization in MT or NT than CT surface soils was also found by Alvarez et al. (1995), SalinasGarcia et al. (1997), Wright et al. (2005), and Oorts et al. (2006) and probably depended on the organic C contents. In the subsoil, the cumulative and the specific respiration of the MT system was lower than in the surface soil, while it generally remained at the same level for CT soils (Fig. 3, Table 3). Overall, $\mathrm{C}$ mineralization in the subsoils was higher from CT than from MT with significant differences between $\mathrm{CT}_{\text {bulk }}$ and $\mathrm{MT}_{\text {bulk. }}$. The main reason for this is that harvest residues are concentrated in the surface soil in the MT treatments, whereas in the CT treatment, an accumulation of the harvest residues mainly occurred in the lower third of the Ap horizon.

The incubation of md soils $\left(\mathrm{MT}_{\mathrm{md}}, \mathrm{CT}_{\mathrm{md}}\right)$ did not generally result in a significantly higher $\mathrm{C}$ mineralization compared to the respective bulk soils, except for the $\mathrm{MT}_{\mathrm{md}}$ subsoil (Fig. 3). Probably the physical stabilization of OM stored in the macroaggregates does not depend on a mechanism protecting very labile $\mathrm{C}$ with a turnover time of weeks but rather on the formation of new macroaggregates, which may be higher than the destruction of macroaggregates within a few days. For instance, Bossuyt et al. (2001) found $25 \%$ of the bulk soil in new-built macroaggregates after 6 days of incubation. However, for the latter hypothesis, marked differences in the respiration would be expected in the initial phase of the incubation, which were not observed for the MT surface soil (Fig. 3).

In their review, Balesdent et al. (2000) showed for most incubated soils an increase of mineralization rates after destruction of macroaggregates, except for soils with very low clay contents. Ratios of $\mathrm{C}$ mineralization of crushed soils to uncrushed soils generally ranged from 0.75 to 2.3 with an extreme value of 10.8. Recently, Oorts et al. (2006) reported a reduction of potential $\mathrm{C}$ mineralization after destruction of macroaggregates in an NT surface soil. Overall, different incubation conditions and crushing methods make interpretations difficult and indicate the need for standardizing aggregate destruction and incubation
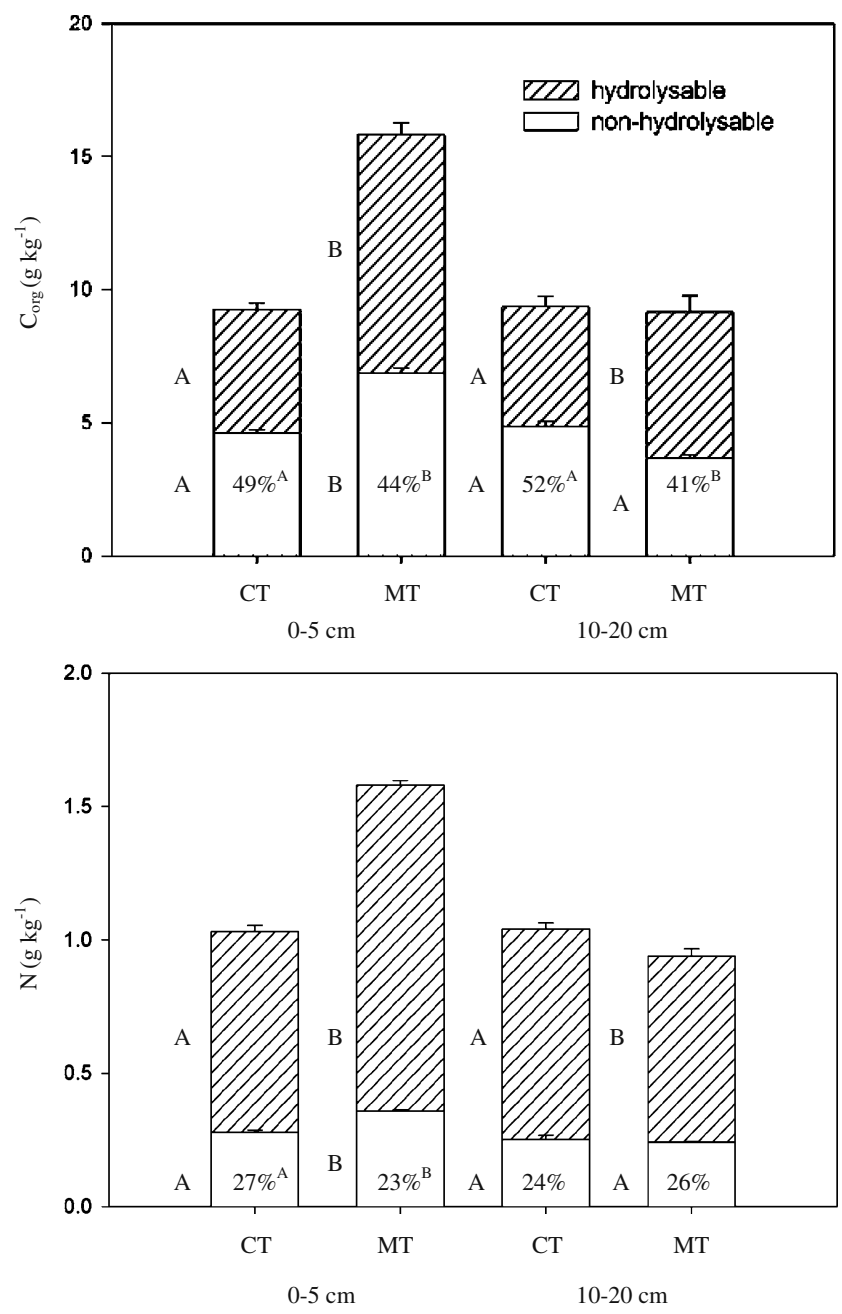

Fig. 4 Concentrations of hydrolysable and nonhydrolysable $\mathrm{C}_{\text {org }}$ and $\mathrm{N}$ among tillage systems (CT and MT) and depths (means and standard errors, $n=4)$. Percentages give the contribution of nonhydrolysable $\mathrm{C}_{\text {org }}$ and $\mathrm{N}$ to total Corg and total $\mathrm{N}$. Letters indicate significant differences $(p \leq 0.05)$ among tillage systems 
procedure in order to gain a better quantitative understanding of OM protection in soils.

The determination of the microbial biomass showed large differences between the tillage systems after 28 days of incubation. In the surface soil, $\mathrm{C}_{\text {mic }}$ was 3.6 and 4.0 times greater in the $\mathrm{MT}_{\text {bulk }}$ and $\mathrm{MT}_{\mathrm{md}}$ treatments, respectively, compared to the respective CT treatments. In the subsoil, CT soil showed higher values, but differences between tillage treatments were much less pronounced than in the surface soil (Table 3). Furthermore, the percentage of $\mathrm{C}_{\text {org }}$ present as $\mathrm{C}_{\text {mic }}$ was significantly higher in $\mathrm{MT}_{\text {bulk }}$ and $\mathrm{MT}_{\mathrm{md}}$ than in the respective CT surface soils, while no differences between tillage systems were found in the subsoil (Table 3). The differences found between MT and $\mathrm{CT}$ in the distribution of OM (Table 1) and of microbial biomass (Table 3) agree with findings of various other studies (e.g., Ahl et al. 1998; Kushwaha et al. 2001; Spedding et al. 2004) and depend on the difference in the depth of incorporation of plant residues in the two tillage systems (Kandeler et al. 1999; Stockfisch et al. 1999; Kushwaha et al. 2001; Jacobs et al. 2009).

\section{Effect of long-term tillage on recalcitrant, biochemically stabilized OM}

In the surface soil, the content of nonhydrolysable $\mathrm{C}$ was slightly greater in the MT soil than in the CT soil (Fig. 4), whereas the difference in the content of hydrolysable $\mathrm{C}$ was more pronounced. The proportion of nonhydrolysable, $\mathrm{C}_{\mathrm{org}}$ to total $\mathrm{C}_{\text {org }}$, was even lower in the MT than in the $\mathrm{CT}$ soils (Fig. 4). Hydrolysable and nonhydrolysable $\mathrm{N}$ followed the same trend (Fig. 4). Overall, the data indicate that MT has a physical rather than a biochemical stabilization effect.

In the subsoil, the proportion of nonhydrolysable $\mathrm{C}_{\text {org }}$ to total $\mathrm{C}_{\text {org }}$ was significantly lower in MT than in CT, while no differences were detected for $\mathrm{N}$. The lower contribution of nonhydrolysable, biochemical recalcitrant, $\mathrm{C}_{\text {org }}$ to total $\mathrm{C}_{\text {org }}$ of MT soils confirms that which was reported by Collins et al. (2000) and the hypothesis that the proportion of resistant SOM will increase with SOM depletion (e.g., Kiem et al. 2000; Plante et al. 2004).

\section{Conclusions}

This study indicates that a lower occurrence of water-stable macroaggregates in a $\mathrm{CT}$ soil compared to an MT soil cannot be mainly attributed to a physical disruption of aggregates by ploughing. Directly after tillage and residue incorporation, considerable amounts of new macroaggregates were formed, especially in the MT surface soil due to the high concentration of crop residues. In the short-term, macroaggregates can store the surplus of $\mathrm{OM}$ found under
MT compared to CT systems. Furthermore, it was shown that the surplus of OM in MT is stored in a biochemically degradable fraction, especially in the surface soil, and with ongoing time after tillage, macroaggregates disrupt into stabilized microaggregates, which provide longer preservation of OM.

Acknowledgements This project is financed by the Deutsche Forschungsgemeinschaft (DFG-Research Training Group 1397 "Regulation of soil organic matter and nutrient turnover in organic agriculture").

We thank Philipp Aurin, Anita Bartlitz, Helmut Gehrke, Ramona Kolenics, Margit Rode, and Anja Sawallisch for their technical advice and their help.

\section{References}

Ahl C, Joergensen RG, Kandeler E, Meyer B, Woehler V (1998) Microbial biomass and activity in silt and sand loams after longterm shallow tillage in central Germany. Soil Tillage Res 49:93104

Alvarez R, Díaz RA, Barberob N, Santanatoglia OJ, Blotta L (1995) Soil organic carbon, microbial biomass and $\mathrm{CO}_{2}-\mathrm{C}$ production from three tillage system. Soil Tillage Res 33:17-28

Álvaro-Fuentes J, Arrúe JL, Gracia R, López MV (2007) Soil management effects on aggregate dynamics in semiarid Aragon (NE Spain). Sci Total Environ 378:179-182

Balesdent J, Chenu C, Balabane M (2000) Relationship of soil organic matter dynamics to physical protection and tillage. Soil Tillage Res 53:215-230

Beare MH, Hendrix PF, Cabrera ML, Coleman DC (1994) Aggregateprotected and unprotected organic matter pools in conventional- and no-tillage soils. Soil Sci Soc Am J 58:787-795

Beare MH, Hu S, Coleman DC, Hendrix PF (1997) Influences of mycelial fungi on soil aggregation and organic matter storage in conventional and no-tillage soils. Appl Soil Ecol 5:211-219

Bossuyt H, Denef K, Six J, Frey SD, Merckx R, Paustian K (2001) Influence of microbial populations and residue quality on aggregate stability. Appl Soil Ecol 16:195-208

Bronick CJ, Lal R (2005) Soil structure and management: a review. Geoderma 124:3-22

Cambardella CA, Elliott ET (1993) Carbon and nitrogen distribution in aggregates from cultivated and native grassland soils. Soil Sci Soc Am J 57:1071-1076

Collins HP, Elliott ET, Paustian K, Bundy LG, Dick WA, Huggins DR, Smucker AJM, Paul EA (2000) Soil carbon pools and fluxes in long-term corn belt agroecosystems. Soil Biol Biochem 32:157-168

Daraghmeh OA, Jensen JR, Petersen CT (2009) Soil structure stability under conventional and reduced tillage in a sandy loam. Geoderma 150:64-71

De Gryze S, Six J, Merckx R (2006) Quantifying water-stable soil aggregate turnover and its implication for soil organic matter dynamics in a model study. Eur J Soil Sci 57:693-707

Ehlers W, Werner D, Mähner T (2000) Wirkung mechanischer Belastung auf Gefüge und Ertragsleistung einer Löss-Parabraunerde mit zwei Bearbeitungssystemen. J Plant Nutr Soil Sci 163:321-333

Ellert BH, Janzen HH, McConkey BG (2001) Measuring and comparing soil carbon storage. In: Lal R, Kimble JM, Follet RF, Stewart BA (eds) Assessment methods for soil carbon. CRC Press, Boca Raton, FL, pp 131-146

Elliott ET, Palm CA, Reuss DE, Monz CA (1991) Organic matter contained in soil aggregates from a tropical chronosequence: 
correction for sand and light fraction. Agric Ecosyst Environ $34: 443-451$

Heinze S, Raupp J, Joergensen RG (2009) Effects of fertilizer and spatial heterogeneity in soil $\mathrm{pH}$ on microbial biomass indices in a long-term field trial of organic agriculture. Plant Soil. doi:10.1007/s11104-009-0102-2

Helfrich M, Ludwig B, Potthoff M, Flessa H (2008) Effect of litter quality and soil fungi on macroaggregate dynamics and associated partitioning of litter carbon and nitrogen. Soil Biol Biochem 40:1823-1835

Jacobs A, Rauber R, Ludwig B (2009) Impact of reduced tillage on carbon and nitrogen storage of two Haplic Luvisols after 40 years. Soil Tillage Res 102:158-164

Jastrow JD (1996) Soil aggregate formation and the accrual of particulate and mineral-associated organic matter. Soil Biol Biochem 28:665-676

Joergensen RG, Schmaedeke F, Windhorst K, Meyer B (1995) Biomass and activity of microorganisms in a fuel oil contaminated soil. Soil Biol Biochem 27:1137-1143

Kandeler E, Palli S, Stemmer M, Gerzabek MH (1999) Tillage changes microbial biomass and enzyme activities in particle-size fractions of a Haplic Chernozem. Soil Biol Biochem 31:1253-1264

Kiem R, Knicker H, Körschens M, Kögel-Knabner I (2000) Refractory organic carbon in C-depleted arable soils, as studied by ${ }^{13} \mathrm{C} N M R$ spectroscopy and carbohydrate. Org Geochem 31:655-668

Kushwaha CP, Tripathi SK, Singh KP (2001) Soil organic matter and water-stable aggregates under different tillage and residue conditions in a tropical dryland agroecosystem. Appl Soil Ecol $16: 229-241$

Ludwig B, Schulz E, Merbach I, Rethemeyer J, Flessa H (2007) Predictive modelling of the $\mathrm{C}$ dynamics for eight variants of the long-term static fertilization experiment in Bad Lauchstädt using the Rothamsted Carbon Model. Eur J Soil Sci 58:1155-1163

Oades J (1984) Soil organic matter and structural stability: mechanisms and implications for management. Plant Soil 76:319-337

Olchin GP, Ogle S, Frey SD, Filley TR, Paustian K, Six J (2008) Residue carbon stabilization in soil aggregates of no-till and tillage management of dryland cropping systems. Soil Sci Soc Am J 72:507-513

Oorts K, Nicolardot B, Merckx R, Richard G, Boizard H (2006) C and $\mathrm{N}$ mineralization of undisrupted and disrupted soil from different structural zones of conventional tillage and no-tillage systems in northern France. Soil Biol Biochem 38:2576-2586

Paul EA, Morris SJ, Conant RT, Plante AF (2006) Does the acid hydrolysis-incubation method measure meaningful soil organic carbon pools? Soil Sci Soc Am J 70:1023-1035
Paustian K, Six J, Elliott ET, Hunt HW (2000) Management options for reducing $\mathrm{CO}_{2}$ emissions from agricultural soils. Biogeochemistry 48:147-163

Plante AF, Feng Y, McGill WB (2002) A modeling approach to quantifying soil macroaggregate dynamics. Can J Soil Sci 82:181-190

Plante AF, Chenu C, Balabane M, Mariotti A, Righi D (2004) Peroxide oxidation of clay-associated organic matter in a cultivation chronosequence. Eur J Soil Sci 55:471-478

Plante AF, Conant RT, Paul EA, Paustian K, Six J (2006) Acid hydrolysis of easily dispersed and microaggregate-derived siltand clay-sized fractions to isolate resistant soil organic matter. Eur J Soil Sci 57:456-467

Salinas-Garcia JR, Hons FM, Matocha JE, Zuberer DA (1997) Soil carbon and nitrogen dynamics as affected by long-term tillage. Biol Fertil Soils 25:182-188

Six J, Elliott ET, Paustian K, Doran JW (1998) Aggregation and soil organic matter accumulation in cultivated and native grassland soils. Soil Sci Soc Am J 62:1367-1377

Six J, Paustian K, Elliott ET, Combrink C (2000a) Soil structure and organic matter: I. Distribution of aggregate-size classes and aggregate-associated carbon. Soil Sci Soc Am J 64:681-689

Six J, Elliott ET, Paustian K (2000b) Soil macroaggregate turnover and microaggregate formation: a mechanism for $\mathrm{C}$ sequestration under no-tillage agriculture. Soil Biol Biochem 32:2099-2103

Spedding TA, Hamel C, Mehuys GR, Madramootoo CA (2004) Soil microbial dynamics in maize-growing soil under different tillage and residue management systems. Soil Biol Biochem 36:499-512

Stockfisch N, Forstreuter T, Ehlers W (1999) Ploughing effects on soil organic matter after twenty years of conservation tillage in Lower Saxony, Germany. Soil Tillage Res 52:91-101

Vance ED, Brookes PC, Jenkinson DS (1987) An extraction method for measuring soil microbial biomass C. Soil Biol Biochem 19:703-707

von Lützow M, Kögel-Knabner I, Ekschmitt K, Matzner E, Guggenberger G, Marschner B, Flessa H (2006) Stabilization of organic matter in temperate soils: mechanisms and their relevance under different soil conditions - a review. Eur J Soil Sci $57: 426-445$

Wright AL, Hons FM, Matocha JE Jr (2005) Tillage impacts on microbial biomass and soil carbon and nitrogen dynamics of corn and cotton rotations. Appl Soil Ecol 29:85-92

Zotarelli L, Alves BJR, Urquiaga S, Boddey RM, Six J (2007) Impact of tillage and crop rotation on light fraction and intraaggregate soil organic matter in two Oxisols. Soil Tillage Res 95:196-206 